\title{
AKTIVITAS ANTIMIKROBA YOGURT BERBASIS AIR KELAPA MENGHAMBAT BAKTERI PATOGEN SECARA IN VITRO
}

\author{
LINDAWATI, S.A., HANIYAH, Y.S., MIWADA I N.S., INGGRIATI, N.W.T., \\ HARTAWAN, M., DAN SUARTA, I G.D. \\ Fakultas Peternakan Universitas Udayana,Denpasar \\ e-mail:srianggrenilindawati@yahoo.co.id
}

\begin{abstract}
ABSTRAK
Yogurt merupakan minuman susu yang difermentasi dengan menggunakan bakteri asam laktat Lactobacillus bulgaricus dan Streptococcus thermophyllus sebagai starter. Tujuan penelitian untuk mengetahui kemampuan tertinggi dari yogurt berbasis air kelapa dalam menghambat pertumbuhan bakteri pathogen (Salmonella, Staphylococcus, Klebsiela pneumonia dan E.coli) secara in vitro. Penelitian ini menggunakan rancangan acak lengkap (RAL) dengan empat perlakuan dan empat ulangan. Keempat perlakuan tersebut: Ko: susu skim 12\%+air; K1: susu skim 12\%+air kelapa gading; K2: susu skim 12\%+kelapa gading bulan; K3: susu skim 12\%+air kelapa hijau. Peubah yang diamati adalah aktivitas antimikroba yogurt terhadap bakteri pathogen (Salmonellatyphi, Staphylococcus, Klebsiella pneumonia dan E.coli), total plate count (TPC), total bakteri asam laktat dan E,coli. Hasil penelitian menunjukkan bahwa aktivitas antimikroba tertinggi diperoleh pada yogurt berbasis air kelapa bulan terhadap bakeri Salmonella typhi dan Staphylococcus masing-masing sebesar 0,21 dan 0,26 cm dengan

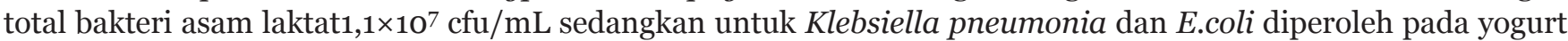
berbasis air kelapa gading sebesar 0,38 dan $0,64 \mathrm{~mm}$ dengan total bakteri asam laktat $3,1 \times 10^{6} \mathrm{cfu} / \mathrm{mL}$.Dari hasil penelitian dapat disimpulkan bahwa yogurt berbasis air kelapa gading, bulan, hijau dan tanpa air kelapa memiliki aktivitas antimikroba berspektrum luas (menghambat bakteri gram positif dan negatif).
\end{abstract}

Kata kunci: aktivitas antimikroba, yogurt, air kelapa, bakteri patogen

\section{ANTIMICROBIAL ACTIVITY OF YOGURT-BASED COCONUT WATER INHIBITS PATHOGEN BACTERIA IN VITRO}

\begin{abstract}
Yogurt is a fermented milk drink using lactic acid bacteria as of Lactobacillus bulgaricus and Streptococcus thermophyllus as a starter. The purpose of the study to determine the ability of the highest of coconut milk-based yogurt in inhibiting the growth of pathogenic bacteria (Salmonella,Staphylococcus, Klebsiela pneumonia and E. coli) in vitro. This study used a completely randomized design (CRD) with four treatments and four replications. The treatments were Ko: 12\% skim milk + water; K1: 12\% skim milk + coconut water of "Gading"; K2: 12\% skim milk + coconut water of "Bulan"; K3: 12\% skim milk + coconut water of "Ijo". Parameters observed were antimicrobial activity of yogurt against some pathogenic bacteria (Salmonella typhi, Staphylococcus, Klebsiella pneumoniae and $E$. coli), total plate count (TPC), total lactic acid bacteria (BAL) and E, coli. The results showed that the highest antimicrobial activity was obtained based on yogurt based coconut water of "Bulan" against Salmonella typhi and Staphylococcus bacterial respectively 0.21 and $0.26 \mathrm{~mm}$ with a total lactic acid bacteria $1.1 \times 10^{7} \mathrm{cfu} / \mathrm{mL}$ whereas for Klebsiella pneumoniae and E. coli obtained in yogurt based coconut water of "Gading" at 0.38 and $0.64 \mathrm{~mm}$ with a total lactic acid bacteria $3.1 \times 10^{6} \mathrm{cfu} / \mathrm{g}$. It can be concluded that coconut milk-based yogurt "gading, "bulan", "ijo" and without the coconut water has a broad spectrum of activity antimicrobial (inhibits gram positive bacteria and negative).
\end{abstract}

Keywords: antimicrobial activity, yogurt, coconut water, bacterial pathogens

\section{PENDAHULUAN}

Buah kelapa merupakan salah satu bahan baku dalam pengolahan pangan. Salah satu limbahnya berupa air kelapa. Air kelapa juga mempunyai manfaat yang cukup penting dalam pengolahan pangan untuk kesehatan. Martini et al. (2010) dan Mantra et al. (2011) melaporkan bahwa air kelapa dapat dipakai sebagai starter dalam pembuatan virgin coconut oil( $\mathrm{VCO}$ ) melalui proses fermentasi yang mempunyai aspek ke- 
sehatan. Ruaida (2009) menyatakan bahwa air kelapa bersifat rehidrasi, isotonik dan dapat dipakai sebagai media pembuatan nata de coco. Hariyadi (2009) menyatakan bahwa air kelapa kaya dengan nutrisi, seperti kalium, gula (1,7-2,6\%), protein(0,07-0,55\%). Young et al. (2009) menyatakan bahwa air kelapa memiliki rasa manis dan empat jenis asam amino (Arginin $133 \mathrm{mg} /$ $\mathrm{mL}$; Alanin $312 \mathrm{mg} / \mathrm{mL}$; Cystin 1,17 mg/mL dan serin $111 \mathrm{mg} / \mathrm{mL}$ ). Fardiaz (1996) melaporkan bahwa melalui fermentasi asam laktat, ternyata air kelapa mampu menekan pertumbuhan E.coli secara in vitro. Berdasarkan sifat-sifat dari air kelapa diatas, maka dilakukan penelitian dengan penambahan air kelapa pada proses pembuatan susu fermentasi (yogurt), meskipun telah terbukti bahwa susu fermentasi mampu menghambat pertumbuhan bakteri pathogen (Salmonella penyebab diare, Staphylococcus penyebab luka bernanah pada kulit, Klebsiella pneumonia menyebabkan gangguan pernafasan dan E.coli selain menyebabkan diare, demam juga sebagai bakteri indikator sanitasi), seperti yang dilaporkan oleh Lindawati et al. (2010) dan Rarah (2002). Berdasarkan sifat-sifat air kelapa, maka penelitian ini diupayakan diversifikasi susu fermentasi dengan berbasis air kelapa "gading","bulan" dan "hijau" dengan menggunakan starter yogurt yang mengandung Lactobacillus bulgaricus dan Streptococcus thermophillus sebagai minuman kesehatan yang dibuktikan melalui evaluasi aktivitas antimikrobanya terhadap bakteri pathogen (Salmonella,Staphylococcus, Klebsiellapneumonia dan E.coli)secara in vitro.

\section{MATERI DAN METODE}

\section{Materi}

Materi yang digunakan dalam penelitian ini, yaitu susu skim, starter yogurt yang diperoleh dari swalayan di Denpasar. Air kelapa (kelapa gading,bulan, dan hijau) diperoleh dari perkebunan rakyat. Bakteri uji (Salmonella, Staphylococcus, Klebsiela pneumonia dan E.coli) diperoleh dari Laboratorium Mikrobiologi Fakultas Kedokteran Universitas Udayana.

\section{Metode}

Rancangan yang digunakan dalam penelitian ini adalahrancangan acak lengkap (RAL) dengan empat perlakuan dan empat ulangan. Keempat perlakuan tersebut, Ko: susu skim $12 \%+$ air; K1: susu skim 12\%+air kelapa gading; K2: susu skim $12 \%+$ air kelapa bulan dan K3 susu skim $12 \%$ + air kelapa hijau.

\section{Pembuatan Yogurt Berbasis Air Kelapa}

Proses pembuatan yogurt menurut Ot'es dan Cagindi (2003), dengan cara: susu skim dihomogenkan masing-masing dengan air kelapa gading, bulan dan hijau, dipasteurisasi pada suhu $85^{\circ} \mathrm{C}$ selama 10 menit kemudian suhu diturunkan sampai $22^{\circ} \mathrm{C}$, dicampur dengan starter sebanyak 3\%, dan dihomogenkan. Selanjutnya susu tersebut dimasukkan ke dalam toples sesuai dengan jumlah perlakuan dan ulangan, masingmasing sebanyak $50 \mathrm{ml}$, diinkubasi pada suhu ruang $25^{\circ} \mathrm{C}$ selama $24 \mathrm{jam}$. Kemudian dianalisis sesuai dengan peubah. Untuk lebih jelas dapat dilihat pada Gambar1.

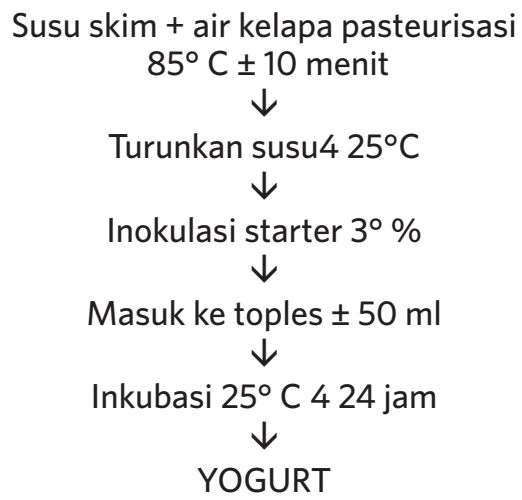

Gambar 1. Proses pembuatan yogurt berbasis air kelapa

\section{Persiapan Bakteri Uji}

Persiapan bakteri uji (Salmonella, Staphylococcus, Klebsilla pneumonia dan E.coli) dilakukan dengan meremajakan menggunakan media Nutrien Broth (NB).Dari media NB yang sudah mengandung bakteri pathogen, diambil sebanyak $100 \mu \mathrm{l}$ kemudian diinokulasikan ke dalam $9 \mathrm{~mL}$ media NB dan diinkubasi $24-48$ jam $\pm 37^{\circ} \mathrm{C}$.

\section{Peubah yang Diamati}

Peubah yang diamati, aktivitas antimikroba terhadap bakteri pathogen/bakteri uji (Salmonella, Staphylococcus, Klebsilla pneumonia dan E.coli), total bakteri asam laktat (BAL), dan E.coli.

\section{Uji Aktivitas Antimikroba}

Penentuan aktivitas antimikroba mengacu pada NCCLS (2000) metode difusi sumur, dengan cara: bakteri uji yang sudah disiapkan (yang sudah diinkubasi 24 jam) diencerkan hingga populasi $10^{7} \mathrm{cfu} / \mathrm{mL}$. Media Nutrien Agar (NA) yang sudah memadat, diinokulasi dengan bakteri uji dan diratakan dengan batang bengkok hingga homogen. Kemudian media tersebut dilubangi dengan pipet tip's plastic sehingga berupa sumur. Ke dalam sumur tersebut diisi $50 \mu$ l yogurt dan diinkubasi pada suhu $37^{\circ} \mathrm{C} \pm 24 \mathrm{jam}$. Semua cawan petri dibuat duplo. Hasil positif, apabila ada zona bening disekitar sumur tersebut dan diukur dengan menggunakan jangka sorong. 


\section{Total BAL dan E.coli}

Metode analisis total BAL dan E.coli mengacu pada Swanson et al. (1992), masing-masing menggunakan metode tuang dan sebar. Yogurt dipipet sebanyak $5 \mathrm{~mL}$ dan dimasukkan ke dalam erlenmeyer yang sudah berisi $45 \mathrm{~mL}$ pepton sehingga diperoleh tingkat pengenceran $10^{-1}$. Dari tingkat pengenceran tersebut diencerkan lagi hingga diperoleh $10^{-2}$. Demikian seterusnya hingga diperoleh tingkat pengenceran $10^{-6}$. Untuk BAL, penanaman dilakukan pada tingkat pengenceran $10^{-5}$ dan $10^{-6}$ sedangkan untuk E.coli penanaman dilakukan pada tingkat pengenceran $10^{-1}$ dan $10^{-2}$. Masingmasing penanaman dilakukan duplo dan diinkubasi pada inkubator pada suhu $37^{\circ} \mathrm{C} \pm 24$ jam. Metode yang digunakan untuk menghitung koloni BAL dan E.coli, metode hitungan cawan, dengan memilih koloni yang tumbuh berkisar antara 25-250 koloni dalam cawan petri (Swanson et al., 1992), dengan rumus:

$$
\text { Jumlah koloni } \times \frac{1}{\text { faktor pengenceran }}
$$

\section{Analisis Statistik}

Data yang diperoleh, dianalisis dengan sidik ragam, apabila terdapat perbedaan yang nyata (Po,05), maka dilanjutkan dengan Uji Duncan's (Steel dan Torrie, 1998). Untuk data mikroba sebelum dianalisis, ditransformasi ke dalam $\log \mathrm{x}$

\section{HASIL}

\section{Aktivitas Antimikroba Yogurt Berbasis Air Kela- pa terhadap Mikroba Patogen Salmonella typhi}

Hasil penelitian menunjukkan bahwa, aktivitas antimikrobayogurtberbasis air kelapa gading (K1), bulan (K2), dan hijau (K3) tidak nyata (Po,05) kemampuannya menghambat pertumbuhan Salmonella dibandingkan yogurt tanpa air kelapa (Ko). Walaupun secara statistik tidak nyata $(\mathrm{Po}, 05)$, namun dilihat dari data pada Tabel 1. semua perlakuan mempunyai aktivitas antimikroba cenderung lebih tinggi daripada tanpa air kelapa (0,10 $\mathrm{cm}$ ) dan tertinggi diperoleh pada perlakuan K2 (bulan) sebesar $0,21 \mathrm{~cm}$.

\section{Escherichia coli}

Yogurt berbasis air kelapa pada semua perlakuan memiliki aktivitas antimikroba terhadap E.coli dengan kisaran sebesar 0,09-0,64 cm. Perlakuan K1, K2, dan $\mathrm{K} 3$ nyata $(\mathrm{P}<0,05)$ lebih tinggi masing-masing sebesar 85,93\%; 71,87\% dan 66,66\% dibandingkan dengan KO. Begitu juga pada perlakuan $\mathrm{K} 1$ nyata $(\mathrm{P}<0,05)$ lebih tinggi 50\% dibandingkan $\mathrm{K} 2$ dan 57,81\% dibanding K3. Akan tetapi perlakuan K2 tidak nyata $(\mathrm{P}>0,05)$ lebih tinggi dibandingkan $\mathrm{K}_{3}$. Namun dilihat dari data
Tabel 1. Aktivitas Antimikroba Yogurt Berbasis Air Kelapa terhadap Bakteri Patogen (Salmonella typhi, Escheriehia coli, Klebsiela pneumonia, dan Staphylococcus)

\begin{tabular}{|c|c|c|c|c|c|}
\hline \multirow{2}{*}{ Peubah $(\mathrm{cm})$} & \multicolumn{4}{|c|}{ Perlakuan } & \multirow{2}{*}{ SEM } \\
\hline & $\mathrm{KO}$ & K1 & $\mathrm{K} 2$ & K3 & \\
\hline Salmonella typhi & $0,11^{a}$ & $0,20^{a}$ & $0,21^{a}$ & $0,16^{a}$ & 0,016 \\
\hline Escheriehia coli & $0,09^{a}$ & $0,64^{a}$ & $0.32^{b}$ & $0.27^{b}$ & 0.017 \\
\hline Klebsiella pneumonia & $0,07^{a}$ & $0,38^{c}$ & $0,30^{b c}$ & $0.24^{b}$ & 0,011 \\
\hline Staphyloccus aereus & $0,11^{\mathrm{a}}$ & $0,21^{a}$ & $0,26^{a}$ & $0,24^{a}$ & 0,017 \\
\hline
\end{tabular}

Keterangan :

1. Perlakuan KO: Susu skim $12 \%+$ Air

Perlakuan KI: Susu skim 12\% + Air Keiapa "Gading"

Perlakuan K2: Susu skim 12\% + Air Kelapa "Bulan"

Perlakuan K3: Susu skim 12\% + Air Kelapa "Hijau"

2. SEM: "Standard Error of the Treatment Means "

3. Angka yang diikuti oleh huruf yang sama pada baris yang sama berarti berbeda tidak nyata $(P>0,05)$

pada Tabel 1, K2 cenderung lebih tinggi daripada K3. Aktivitas tertinggi diperoleh pada air kelapa gading sebesar $0,64 \mathrm{~cm}$.

\section{Klebsiella pneumonia}

Analisa statistik menunjukkan bahwa daya hambat anti mikroba terhadap Klebsiella pneumonia pada perlakuan semua perlakuan $\mathrm{Kl}$, K2, dan $\mathrm{K} 3$ nyata $(\mathrm{P}<0,05)$ lebih tinggi masing-masing sebesar $81,57 \% ; 76,66 \%$ dan 70,83\% dibandingkan Ko. Sedangkan pada perlakuan $\mathrm{K} 1$ tidak nyata $(\mathrm{P}>0,05)$ lebih tinggi dibandingkan pada perlakuan K2 dan K3. Pada perlakuan K2 menunjukkan hasil tidak nyata $(\mathrm{P}>0,05)$ lebih tinggi dibandingkan $\mathrm{K}_{3}$ sebesar 20\% . Dilihat pada Tabel1, aktivitas antimikroba tertinggi diperoleh pada K1 (gading) sebesar o,38 $\mathrm{cm}$ kemudian diikuti K2(bulan) sebesar 0,30 cm dan $\mathrm{K}_{3}$ (ijo) sebesar $0,24 \mathrm{~cm}$.

\section{Staphylococcus aereus}

Hasil penelitian menunjukkan bahwa pada perlakuan K1, K2 dan $\mathrm{K}_{3}$ tidak nyata ( $\mathrm{P}>$ 0.05) lebih tinggi dibandingkan Ko (kontrol) . Walaupun secara statistik tidak nyata $(\mathrm{P}>0,05)$, namun dilihat dari Tabel 1 . semua perlakuan cenderung Iebih tinggi dari Kodan tertinggi diperoleh pada K2 (bulan) sebesar 0.26 kemudian $\mathrm{K}_{3}$ (ijo) sebesar 0,24 dan terendah pada K1 (gading) sebesar $0,11 \mathrm{~cm}$.

\section{Total Bakteri Asam Laktat (BAL)}

Total BAL pada $\mathrm{K} 1$ tidak nyata $(\mathrm{P}>0,05)$ Iebih rendah dibandingkan dengan Ko tetapi nyata $(\mathrm{P}<0,05)$ lebih rendah $71,82 \%$ dibanding K2 dan tidak nyata $(\mathrm{P}>$ o,05) lebih tinggi dari K3. Sedangkan pada perlakuan $\mathrm{K} 2$ nyata $(\mathrm{P}>0,05)$ lebih tinggi dibandingkan Ko, K1 dan K3 masing-masing 47,27, 71,81 dan 80\%. Perlakuan $\mathrm{K} 3$ tidak nyata $(\mathrm{P}>0$, 05$)$ Iebih rendah dibandingkan Ko. Total BAL yang tertinggi diperoleh pada perlakuan K2 dengan koloni sebesar $1,1 \times 10^{7} \mathrm{CFLJ} / g$ kemudian diikuti dengan $\mathrm{K}_{1}\left(3,1 \times 10^{7}\right)$ dan $\mathrm{K}_{3}$ sebesar $2,2 \times 10^{6} \mathrm{cfu} / \mathrm{g}$ 
Tabel 2. Total Bakteri Asam Laktat, Coliform dan E.coliYogurt Berbasis Air Kelapa

\begin{tabular}{|c|c|c|c|c|c|}
\hline \multirow{2}{*}{ Peubah } & \multicolumn{4}{|c|}{ Perlakuan } & \multirow{2}{*}{ SEM } \\
\hline & $\mathrm{KO}$ & $\mathrm{KI}$ & $\mathrm{K} 2$ & K3 & \\
\hline $\begin{array}{l}\text { Total Bakteri Asam } \\
\text { Laktat (CFU/g) }\end{array}$ & $5.8 \times 10^{6 b}$ & $3.1 \times 16^{6 a b}$ & $1.1 \times 10^{7 c}$ & $2.2 \times 10^{6 a}$ & 0.076 \\
\hline Total E.coli (CFU/g & - & - & - & - & - \\
\hline $\begin{array}{ll}\text { Keterangan: } \\
\text { 1. } \\
\text { Perlakuan K0: Susu } \\
\text { Perlakuan K2: Susu } \\
\text { Perlakuan K3: Susu } \\
\text { 2. SEM: "Standard Er } \\
\text { 3. } & \text { Angka yang di ikuti }\end{array}$ & $\begin{array}{l}\text { m 12\%+Air } \\
\text { m 12\% + Air } \\
\text { m } 12 \%+\text { Air } \\
\text { of the Treatm } \\
\text { h huruf yang }\end{array}$ & $\begin{array}{l}\text { Kelapa "Bular } \\
\text { Kelapa "Hijau } \\
\text { nent Means" } \\
\text { sama pada b }\end{array}$ & is yang $\mathrm{s}$ & a tidak ny & $(P>0,05)$ \\
\hline
\end{tabular}

\section{Total E. coli}

Pada semua perlakuan menunjukkan bahwa tidak ditemukan adanya pertumbuhan bakteri E.coli sebagai bakteri sanitasi dari produk.

\section{PEMBAHASAN}

\section{Aktivitas Antimikroba \\ Salmonella typhi}

Hasil penelitian menunjukkan bahwa aktivitas antimikroba yogurt berbasis air kelapa terhadap Salmonella, tertinggi dijumpai pada perlakuan K2 (bulan) kemudian K1 dan K3. Tertingginya aktivitas ini disebabkan, total BAL yang diperoleh pada perlakuan ini (Tabel 2) juga menunjukkan hal yang sama yaitu tertinggi pada k2, bulan $\left(1,1 \times 10^{7} \mathrm{cfu} / \mathrm{g}\right)$ kemudian $\mathrm{K}$, gading (3,1× $\left.10^{6} \mathrm{cfu} / \mathrm{g}\right)$ dan $\mathrm{K}_{3}$, ijo $\left(2,2 \times 10^{6} \mathrm{cfu} / \mathrm{g}\right)$. Tingginya total BAL menyebabkan senyawa-senyawa antimikroba yang dihasilkan selama proses fermentasi lebih cepat dan tinggi. Davidson dan Hoover (1998) menyatakan bahwa selama proses fermentasi susu oleh BAL yang berfungsi sebagai starter (Lactobacillus bulgaricus dan Streptococcus thermophyllus) menghasilkan senyawa-senyawa seperti, asam laktat, hydrogen peroksida dan bakteriosin. Hal ini disebabkan juga pada perlakuan (menggunakan air kelapa) memiliki sifat-sifat, seperti yang dinyatakan oleh Ruaida (2009) bahwa air kelapa bersifat detoksiflkasi. Widodo (2003) menyatakan bahwa yogurt memiliki aktivitas antimikroba berspektrum luas (dapat menghambat pertumbuhan bakteri gram positif dan negatif). Karateristik dari bakteri uji (Salmonella) tergolong bakteri gram negatif, yang memiliki dinding sel lebih tipis sehingga senyawa antimikroba yang dihasilkan mampu merembes dinding sel dan akhirnya merusak bagian sitoplasma.

\section{Escherichla coli(E.coli) dan Klebsiella pneumonia}

Hasil penelitian menunjukkan bahwa perlakuan penambahan air kelapa pada K1 mempunyai aktivitas antimikroba tertinggi kemudian diikuti dengan K2 dan terendah pada $\mathrm{K}_{3}$ terhadap pertumbuhan E.coli dan Klebsiella pneumonia. Hal ini disebabkan bahwa air kelapa mempunyai kandungan nutrisi lebih lengkap dari susu sapi dan Djatmiko (1985) air kelapa mengandung antioksidan yang dapat menghambat pertumbuhan mikroba. Disamping dari sifat-sifat air kelapa, juga didukung oleh adanya antimikroba dari susu fermentasi (hasil biodegradasi Lactobacillus bulgaricus dan Streptococcus thermophillus). Kemampuan aktivitas antimikroba yang lebih tinggi ini disebabkan juga oleh sifat dari bakteri Escherichia coli dan Klebsiella pneumonia tergolong bakteri gram negatif, yakni memiliki dinding sel Iebih tipis dari bakteri gram positif (Fardiaz, 1989), sehingga senyawa antimikroba yogurt berbasis air keiapa mampu merembes atau merusak dinding sel bakteri secara difusi (Alokomi et al., 2000)

\section{Staphylococcus aereus}

Hasil pengujian menunjukkan bahwa aktivitas antimikroba yogurt berbasis air kelapa tertinggi dijumpai pada perlakuan $\mathrm{K} 2$, bulan $(0,26 \mathrm{~cm})$ kemudian diikuti $\mathrm{K}_{3}$, ijo $(0,24)$ dan terendah pada $\mathrm{K} 1$, gading $(0,21 \mathrm{~cm})$ terhadap pertumbuhan bakteri Staphylococcus aureus. Ini berarti yogurt berbasis air kelapa mampu menghambat pertumbuhan Staphylococcus aereus dengan merusak dinding sel, dengan melemahkan system permiabilitasnya, walaupun Staphylococcus aureus termasuk bakteri gram positif yang memiliki dinding sel lebih tebal dari bakteri gram negatip (Efendi, 2007). Ray (2003) melaporkan bahwa susu fermentasi memiliki kemampuan menghambat pertumbuhan bakteri gram positif dan negatif. Demikian juga Widodo (2003) dan Ulusoy et al. (2007) menyatakan bahwa dalam proses biodegradasi oleh bakteri starter (Lactobacillus bulgaricus dan Steptococcus thermophillus)pada susu fermentasi menyebabkan suasana asam, diikuti dengan penurunan $\mathrm{pH}$ yang dapat menghambat pertumbuhan bakteri Staphylococcus aereus. Begitu juga Lindawati dan Martini (2012)melaporkan hasil penelitiannya bahwa air kelapa gading (K1) mengandung karbohidrat tertinggi $(3,2 \%)$ kemudian diikuti K2, "bulan" (2,8\%) dan terendah $\mathrm{K}_{3}$, "ijo" (2,3\%). Tingginya karbohidrat pada air kelapa gading, kemungkinan menyebabkan proses fermentasi karbohidrat (laktosa) oleh starter BAL (Lactobacillus bulgaricus dan Steptococcus thermophillus) lebih lambat sehingga proses terbentuknya senyawasenyawa antimikroba akan terhambat. Hal ini terbukti dari total BAL yang diperoleh pada penelitian ini pada $\mathrm{K} 1$ (gading) paling rendah yaitu $3,1 \times 10^{6} \mathrm{cfu} / \mathrm{g}$ (Tabel 2).

\section{Total Bakteri Asam Laktat, dan E.coli Total Bakteri Asam Laktat(BAL)}

Dari hasil penelitian ternyata diperoleh total BAL berkisar antara $10^{6}-10^{7} \mathrm{CFU} / \mathrm{g}$. Total BAL tertinggi diperoleh pada perlakuan K2 (Bulan) sebesar 1,1× $10^{7} \mathrm{cfu} / \mathrm{g}$. Tingginya ini sesuai dengan hasil penelitian 
Lindawati dan Martini (Unpublish, 2012) melaporkan bahwa $\mathrm{pH}$ dari air kelapa bulan sebesar 4,69, air kelapa gading $(4,86)$ dan air kelapa ijo $(4,82)$. pH dari air kelapa bulan lebih memberikan kondisi asam sehingga pertumbuhan BAL lebih cepat. Widodo (2003) menyatakan bahwa dalam proses fermentasi susu (yogurt), yang didominasi oleh bakteri starter (Lactobacillus bulgaricus dan Streptococcus termophillus). Kedua jenis bakteri ini hidup bersama secara simbiosis mutualisme. Lactobacillus bulgaricus mendegradasi protein menjadi asam amino, lisin, histidin yang menstimulir Streptococcus termophillus untuk tumbuh sehingga suasana menjadi lebih asam. Setelah bakteri ini mencapai fase stasioner, Lactobacillus bulgaricus tumbuh lebih cepat karena lebih tahan terhadap keasaman tinggi. Adanya pertumbuhan kedua BAL ini menyebabkan asam lebih cepat diproduksi diikuti dengan penurunan asam.

\section{Total E.coli}

Dari hasil penelitian ini tidak dijumpai adanya pertumbuhan bakteri E.coli. Hal ini berarti kondisi sanitasi dalam penelitian terjaga sangat baik. Fardiaz (1996) menyatakan bahwa E.coli merupakan indikator bakteri sanitasi. Hal ini disebabkan juga Escherichia coli termasuk bakteri gram negatif yang mempunyai dinding sel lebih tipis sehingga senyawa antimikroba dari yogurt berbasis air kelapa maupun tanpa air kelapa mampu merembes ke dinding sel bakteri.

Dari hasil penelitian dapat disimpulkan bahwa, yogurt berbasis air kelapa "Bulan" tertinggi menghambat pertumbuhan bakteri pathogen Salmonella dan Staphylococcus sebesar 0,21 dan 0,26 cm, sedangkan yogurt air kelapa gading mampu menghambat E.coli dan Klebsiella pneumonia sebesar 0,64 dan $0,38 \mathrm{~cm}$ dengan total bakteri asam laktat berkisar $10^{6}-10^{7} \mathrm{cfu} / \mathrm{g}$.

\section{UCAPAN TERIMA KASIH}

Pada kesempatan ini diucapkan terimakasih kepada Ketua laboratorium Teknologi Hasil ternak dan Mokrobiologi yang telah mengijinkan menggunakan alat-alat dan semua pihak yang telah membantu penelitian ini.

\section{DAFTAR PUSTAKA}

Davidson, F.M., and Hoover, D.G. 1998. Antimicrobial Components from Lactis Acid Bacteria. In: S. Salminen and A. Von Wright (Eds). Lactis Acid Bacteria.Marcel Dekker, Inc. New York.

Fardiaz, S. 1989. Analisis Mikrobiologi Pangan. Pusat Antar Universitas Pangan dan Gizi. IPB, Bogor.

Fardiaz, S., Nuraeni, E.D. dan Kusumaningrum, H. 1996. Pemanfaatan Air Kelapa Untuk Produksi Minuman Sehat Antidiare Melalui Proses Fermentasi Laktat. Bio. Tek dan Industri Pangan, Vol. VII no. 2. Bogor.
Hariyadi, W. 2009. Air Kelapa Muda sebagai Minuman Isotonik Alami. http://www.kompas.com/kompas-cetak/ Q207/ll/iptek/airk28.htm. Diakses tgl 12 April 2012.

Hartawan.M., Lindawati, S.A., Oka, A,A., Utami, I A., dan Kartini, A.A.S. 2010. Peningkatan Teknik Pengolahan Buah Kelapa rnenjadi minyak goreng bermutu (VCC) melalui proses ferrnentasi. Udavana Mengabdi ISSN:14I2-0925. Volume 9 (2): 108-110. Lembaga Pengabdian Kepada Masyarakat. Universitas Udayana.

Lindawati, S.A., Kartini, A.A.S., Hartawan, M., Miwada, I.N., Inggriati, N.W.T., Nuraini, K., Ariana, I.N.T and Umiarti, A.T.. 2010. Antimocrobial Activity of Mother Starter Kefir towards Salmonella, Slaphylococcus and E.coli In Vitro. proceedings.2" International Conference on Biosciences and Biotechnology. Pave the Way to a Better Live. ISBN:978 - 602 - $9042-11-5$. Udayana University Press.

Lindawati,S.A dan Hartawan, M. 2012. Analisa Berbagai Jenis Air Kelapa. Unpublish. Fakultas Peternakan Universitas Udayana.

Mantra, I.B, Yupardi, W.S., Dewantari, M., Umiarti, A.P.T., Ardika, I.N., dan Sriani, N.I.P. 2011. Peningkatan Kecakapan pada Kelompok Wanita Tani Puspasari Banjar Pegongan Desa Taman Kecamatan Abiansemal Kabupaten Badung Melalui Pelatihan Pembuatan VCO dengan Teknologi Fermentasi Alami. Laporan Pengabdian Kepada Masyarakat. Fakultas Petemakan Universitas Udayana.

NCCLS. 2000. Identification and antimicrobial susceptibility testing Salmonella serotype thypii. Manual for Identification and Antimicrobial Susceptibility Testing. World Health Organization. New York.

Ot'es, S and Cagindi, O. 2003. Kefir: A Probiotic Dairy-Composition Nutritional and Therapeutic Aspects. Pakistan J. of Nutrition 2 (2): 54-59

Rarah, R. R. dan NOOR, A.M. 2002. Spektrum aktivitas penghambatan substrat antibiotik biji kefir (tidak dipubikasi). Fakultas Peternakan IPB, Bogor

Ruaida. 2009. Pemakaian Air Kelapa dan Fermentasi terhadap Kualitas Roll. Jurnal Pendidikan dan Keluarga UNP, ISSN 2085 - 4285, Volume 1, Nomor 2, Agustus. Fakultas Teknik Universitas Negeri Padang. Sumatera Barat.

Steel, R.G., dan Torrie, J.H., 1998. "Priciple and Procedure of Statistic". McGraw hill book company Inc. New York.

Swanson,K.M.J., Busta, F.F., Peterson, E.H., and Johnson, M.G.. 1992. Colony Count Methods: In Compendium of Methods for the Microbiological Examination of foods. $3^{\text {rd }}$. Edited by C. Vanderzant., D.F. Splittsoesser. Compiled by the APHA Technical Committee on Microbiological Methods for Foods

Widodo. 2003. Bioteknologi Industri Susu. Lacticia Press, Yogyakarta.

Young, J.W.H.L. Ge.Y.F.Ng dan Tan, SN. 2009. The Chemical Composition and Biological Properties of Coconut (Cocos nucifera L) Water Moleclies 14:5144-5164 